\title{
$\mathrm{Nb}$ 添加非調質高張力鋼板に関する研究（第 $\mathbf{1}$ 報 $)^{*}$
}

$-\mathrm{Nb}$ 添加高張力鋼板の性質の特徵一

$$
\text { 長 谷 部茂. 雄** }
$$

\section{Study of non-heat-treated High Tension Steel Plate Containing Niobium (Report 1$)^{*}$}

-Characteristic of high tension steel plate containing niobium-

\author{
By Shigeo Hasebe**
}

\begin{abstract}
At first the effect of niobium addition on the mechanical and welding properties of low carbon steel small plate as rolled was investigated in laboratory as compared with vanadium addition. Then the properties of large plate as rolled in works of killed and semikilled steel containing niobium, especially the toughness of the plate were investigated.

1) To increase the tensile strength of low carbon steel plate as rolled by $5-6 \mathrm{Kg} / \mathrm{mm}^{2}$ the addition of about $0.05 \%$ vanadium is a little more effective than the one of niobium equivalent to $0.05 \%$ vanadium with respect the impact properties of the plate. But niobium increases the tensile strength of the plate more than vanadium in the range up to about $0.05 \%$ individually.

2) It may be said that we have had for the first time nonheat-treated weldable high tension steel plate with both tensile strength over $60 \mathrm{~kg} / \mathrm{mm}^{2}$ and structure consisting of ferrite and pearlite. The addition of both niobium and vanadium to the low alloy steel containing lower content of carbon further improves the impact properties of the plate as rolled.

3) The high tension steel plate containing niobium has a higher yield ratio as well known and can be welded easily, but the absorbed energy in Charpy impact test of the plate is comparativelly small and this phenomenon is especially controversial in the transverse direction to rolling one. The absorbed energy in Charpy test being small is probably due to the higher tensile strength for the structure consisting of ferrite and pearlite. But the transition temperature of fracture surface in Charpy test is comparativelly good and not worse than the one of low tension steel plate containing no niobium.

4) The new evaluation criteria for brittle fracturc characteristic of structural steels for low temperature application (recently proposed by Japan Welding Engineering Society) adopt the evaluation method by transition temperature of fracture surface in Charpy test, rejecting the one by the absorbed energy. The transition temperature of fracture surface of high tension steel plate containing niobium being good, the small absorbed energy of the plate seems not to be a large defect.

5) The fracture tests on a larger scale such as press-notch crack starter test (wedge impact test) and double tension test of the plate were also carried out. The results of these fracture tests matched the transition temperature of fracture surface in Charpy test and supported the evaluation results by the above new criteria.

6) The tensile strength of carbon steel plate containing no niobium coiled immediately after hotrolling is lowered in general due to the pearlite structure being globularized during slow cooling from coiling temperature, but the one of coiling plate containing niobium is little lowered by precipitation hardening of niobium carbo-nitride. The method to apply globularizing annealing to uncoiled flat plate after hot-rolling may be suitable to improve the impact properties of large plate unable to be coiled.
\end{abstract}

\section{1。緒言}

炭素銅や低合金鋼の諸性質におよぼす $\mathrm{Nb}$ の添加の効

* 原稿受付 昭和11年 9 月 1 日（溶接学会昭和39，40年度表季全国大会 溶接学会溶接治金研究委䝿会第 17 ，18回（1954，資料 No.WM

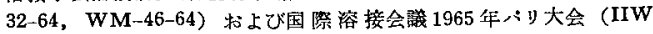
Document No. IX-446-65) にて発表)

** 正員 住友金属工業(株)和歌山製鉄所 Member, Wakayama Works, Sumitomo Metal Industries Co., Ltd.
果についてはかなり以前から知られていた。すなわち 1940年頃加ら米国の特許公報1,2)によって, Nb の添加が 炭素鋼や低合金鋼のオーテナイト結昆粒を微細にする効 果があり，その結果熱処理後の衛揧試験の吸収エネルギ 一を增加させる効果のあることが明らかにされていた。 いっぽう戦後になって1958年頃にはおなじく米国におい て，少量の $\mathrm{Nb}$ を添加することによってセミキルド炭素 
鋼板の熱間圧延のままの引張り強度をかなり增加させる ことができるととがはじめて明らかにされた多，Nbの 炭窒化物の析出硬化学利用した非調䝷型の高張力鋼板で ある。

米国の特許公報1,2)はいずれも熱処理を加えた状態で 使用し之くに溶接性のことを考虑しない機械構造用鋼に 対する $\mathrm{Nb}$ の細粒化の効果化関して特許を請求したもの であったが，1941年の特許公報2のの亿は，低炭菜キル ド鐥による熱間压延のままの小鋼板の引張り強度に㧍よ ぼす Nb の勃果を示す試験成績がわずかではあるがすで に認められる，戦後フェロニオビウムの価格が低下した ことも動機となり, 経済性や溶接性を考慮してはじめて セミキルドの炭素鋼に Nb を添加した高張力鋼板の試作 が行なわれたもの之考元られる。

すでに低炭素りムド鋼板にVを添加して非歪時效性を 与え，その深较り加工性を问上させる試みがおなじ搷米 国において行なわれており，また熱間压延のままの低炭 素鋼板の引張り強度を増加するためにVを添加する試み あ同時に行なわれていたものと想像されるが，1958年䐜 にセミキルド䤱による $\mathrm{Nb}$ 添加鋼板の試作が成功すると まむなく，米国では比較的薄板の溶接構造用高張力銅板 として広範囲に使用されるようになり，その経済性が認 められてきたものである.

このようにして比較的薄板の箢囲ではあるが， $\mathrm{Nb}$ 少量添加した低炭素低マンガン鋼を使って熱間圧延のま まで55キロ級さらに60キ口級の高張力鋼板が我が国でも 造られるようになった。

しかしながらその性躓の特徽はじゅう分には知られて
いない。とくにシャルピー衝撃試験の破面遷移温度は優 れていて，溶接協会の溶接構造用高張力鋁板規格 (WES -135, HPIS-B104T) 飞はじゅう分合格しているすの の、その吸収エネルギーはかなり劣るというような欠点 があり，重要な問題上考えられる，衙撃性質がそれほど 問題上ならない溥板としておもに使用され，また経済的 な面のみが強調されてきたのは，衙撃性質にてのような 特異な点が認められるためである。

本研究はまず第 1 報において, 熱間王延のままで使用 されるこの種の $\mathrm{Nb}$ 添加高張力鎝板の性質の特徽とくに 特異な衝撃性質について報告し, 第 2 報においては，こ の鋼板から溶接して造った鋼管の低温における破壊実験 の成績を報告して，その実用性について検討を加えたも のである.

\section{2. 熱間圧延のままの低炭素鋼板の 譏械的性質におよばす $V$ 上b の影響の比較}

炭素鎆や低合金鋼のオーステナイト結晶粒の微細化に $\mathrm{VPNb}$ の添加の効果があり，その結果衝整性質などの 機械的性質に影影を扰よぼすとと，いっぽうオーステナ イト中に固溶している $\mathrm{V}$ Nb は, 冷却時の変態を押え て橴入れ性を向上し，その後の熱処理中に炭化物などの 形で析出して析出硬化の現象を呈することなどはかなり 以前から知られている。しかしながら熱間压延のままの 状態で使用される低炭䒺鋼板の機栈的性質や溶接性に対 してVと Nb のいずれが優れているかについてはいまだ 明確にされていない．まずての点を明らかにするため

Table 1 Chemical composition of small steel ingots containing Nb $0 \sim 0.30 \%$ and $\mathrm{V} 0 \sim 0.31 \%$ individually

\begin{tabular}{|c|c|c|c|c|c|}
\hline Steel & $\mathrm{C} \%$ & $\mathrm{Si} \%$ & Mn\% & $\mathrm{Nb}$ or $\mathrm{V} \%$ & Type of steel \\
\hline A & 0.14 & 0.04 & 0.90 & 一 & Nb and $V$ free semikilled steel \\
\hline Nb 1 & 0.13 & 0.06 & 0.91 & $\mathrm{Nb} 0.04$ & Nb containing semikilled steel \\
\hline Nb 2 & 0.13 & 0.06 & 0.92 & Nb 0.06 & $"$ \\
\hline $\mathrm{Nb} 3$ & 0.14 & 0.09 & 0.99 & $\mathrm{Nb} 0.15$ & $"$ \\
\hline $\mathrm{Nb} 4$ & 0.13 & 0.09 & 1.00 & $\mathrm{Nb} 0.26$ & $"$ \\
\hline B & 0.13 & 0.29 & 1.32 & - & \multirow{5}{*}{$\begin{array}{c}\text { Nb and V free killed steel } \\
\text { Nb containing killed steel } \\
" \prime \\
\prime \prime \\
"\end{array}$} \\
\hline $\mathrm{Nb} 5$ & 0.14 & 0.30 & 1.20 & $\mathrm{Nb} 0.03$ & \\
\hline $\mathrm{Nb} 6$ & 0.14 & 0.28 & 1.34 & Nb 0.08 & \\
\hline Nb 7 & 0.14 & 0.27 & 1.39 & $\mathrm{Nb} 0.19$ & \\
\hline Nb 8 & 0.14 & 0.33 & 1.40 & $\mathrm{Nb} 0.30$ & \\
\hline V 1 & 0.12 & 0.04 & 0.76 & V 0.05 & \multirow{4}{*}{$\begin{array}{c}\text { V containing semikilled steel } \\
" \prime \\
" \\
"\end{array}$} \\
\hline V 2 & 0.13 & 0.09 & 0.84 & $\mathrm{~V} 0.10$ & \\
\hline V 3 & 0.13 & 0.05 & 0.74 & $\mathrm{~V} 0.21$ & \\
\hline V 4 & 0.14 & 0.09 & 0.81 & $\mathrm{~V} 0.30$ & \\
\hline V 5 & 0.12 & 0.22 & 1.19 & $\mathrm{~V} 0.05$ & \multirow{4}{*}{$\begin{array}{c}\text { V containing killed steel } \\
" \prime \\
" \\
\prime \prime\end{array}$} \\
\hline V 6 & 0.14 & 0.35 & 1.21 & $\mathrm{~V} 0.10$ & \\
\hline V 7 & 0.13 & 0.28 & 1.18 & $\mathrm{~V} 0.20$ & \\
\hline V 8 & 0.17 & 0.28 & 1.20 & $\mathrm{~V} 0.31$ & \\
\hline
\end{tabular}


に，小型止延機を使用して小鋼板による实験を行なっ た.

\section{1. 実験方法}

高周波炉で溶製した重䭪 $100 \mathrm{~kg}$ の小鍼塊を板厚25お よび $40 \mathrm{~mm}$ で板币 $150 \mathrm{~mm}$ の小鋼片に鍛造し, つい で小型圧延機を使用して，25 mm の釦片からは板愿 9 および $13 \mathrm{~mm}$ の小堸板を， $40 \mathrm{~mm}$ の鐥片からは板厚 $25 \mathrm{~mm}$ の小鉿板を王延した、鎆片を $1200^{\circ} \mathrm{C}$ 亿加熱し， 最終王延を $900^{\circ} \mathrm{C}$ で強在下を加えて行なったのち空冷 した.

供試した小銅塊の化学成分を Table 1 および 2 に示 す. Table 1 の鍓塊は Si と $\mathrm{Mn}$ の含有量を異にした

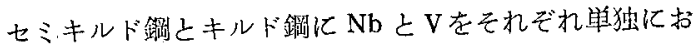
上そ $0.30 \%$ まて添加したあのである。王延のままの状態

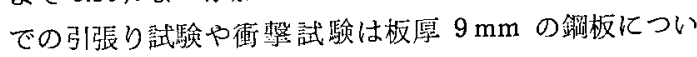

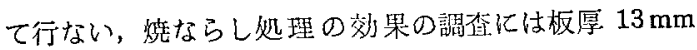
の鋼板を供試した。

Table 2 Chemical composition of small steel ingots containing small amount of $\mathrm{Nb}$

\begin{tabular}{l|c|c|c|c|c|c|c}
\hline \hline Steel & $\mathrm{C} \%$ & $\mathrm{Si} \%$ & $\mathrm{Mn} \%$ & $\mathrm{P} \%$ & $\mathrm{~S} \%$ & $\mathrm{Cu} \%$ & $\mathrm{Nb} \%$ \\
\hline Nb 9 & 0.16 & 0.04 & 0.80 & 0.014 & 0.017 & 0.09 & 0.00 \\
Nb 10 & 0.16 & 0.07 & 0.84 & 0.015 & 0.018 & 0.10 & 0.01 \\
Nb 11 & 0.16 & 0.07 & 0.89 & 0.013 & 0.018 & 0.11 & 0.02 \\
Nb 12 & 0.15 & 0.06 & 0.84 & 0.013 & 0.016 & 0.09 & 0.03 \\
Nb 13 & 0.14 & 0.06 & 0.90 & 0.015 & 0.020 & 0.09 & 0.05 \\
\hline
\end{tabular}

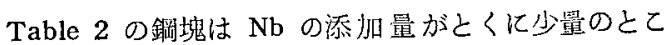
ろの効果を明らかにするために溶製したすので，低炭素 のせミキルド鋼に最大で $0.05 \%$ Nbを港加したあので

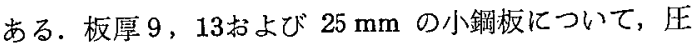
延のままの状態での引張り，衝撃および溶接性試験を行 なった。

\section{2 実験結果}

Table 1 の小鋼塊による実験の結果を Fig. 1 4 4 示す.Fig. 1 および 2 は压延のままの板厚 $9 \mathrm{~mm}$ の小 銊板の降伏点, 引張り強さ，伸びおよび衝盤試験值にお よぼす $\mathrm{Nb}$ とVの効果を比较したすのであり，Fig. 3 および 4 は佬ならしを加えた板厚 $13 \mathrm{~mm}$ の小鋼板につ いておなじく $\mathrm{Nb}$ と Vの効果を比较したものである，乙 れらの実験結果からつぎのてとがわかる。

1）それぞれ $0.05 \%$ 前後までの少量添加の範围では， $\mathrm{Nb}$ の方が引張り強度をより增加させる。この範囲で は，Vの添加量は $\mathrm{Nb}$ のよよ 2 倍が必要というととが できよう。なお $\mathrm{Nb}$ による引張り強度増加の効果をじゅ う分有効に利用するには $0.05 \%$ 程度の添加が適当である う.

2）降伏点および引張り强さを $5 \sim 6 \mathrm{~kg} / \mathrm{mm}^{2}$ 程度增

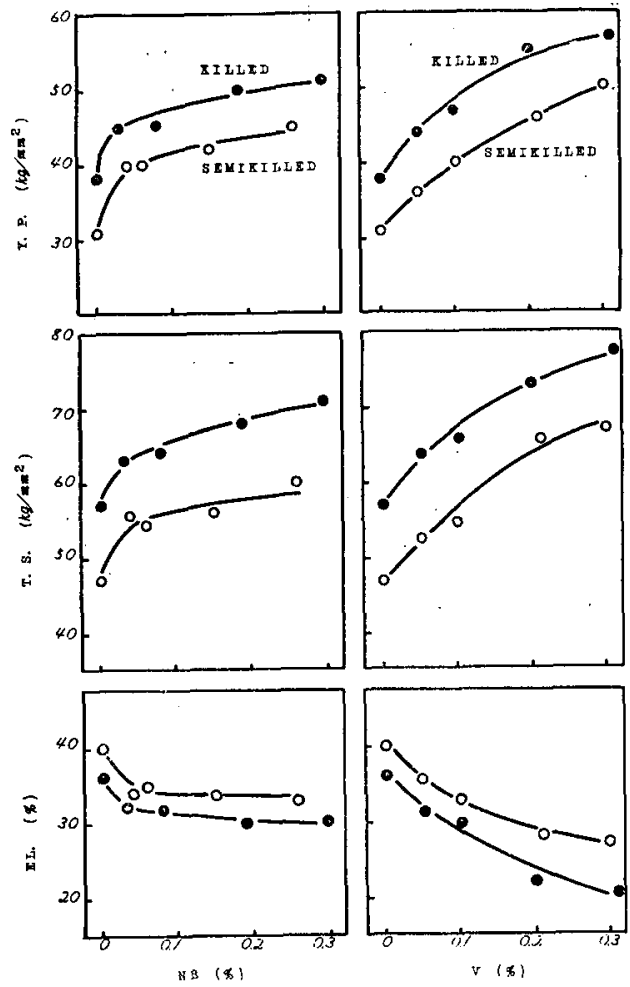

Fig. 1 Comparision between effect of niobium and vanadium addition on tensile properties of small plates $9 \mathrm{~mm}$ thick and as rolled in laboratory (Steels in Table 1)
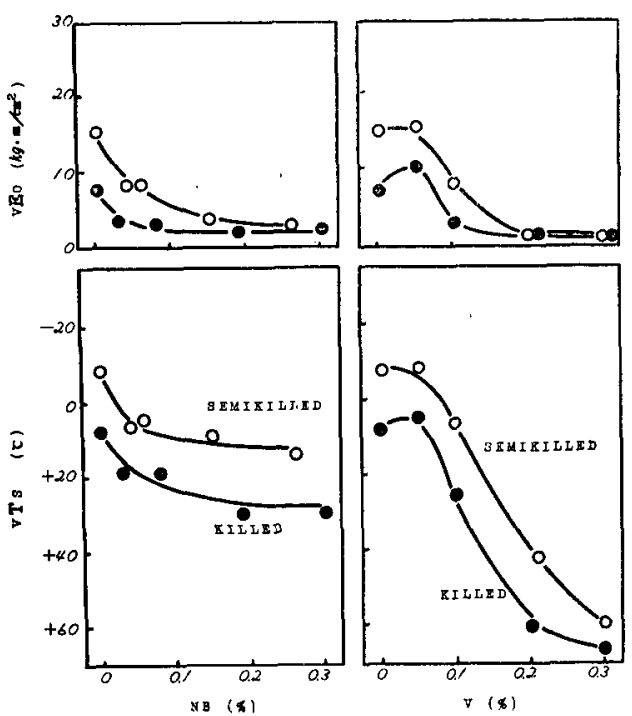

Fig. 2 Comparision between effect of niobium and vanadium addition on $2 \mathrm{~mm} \mathrm{~V}$-notch Charpy impact properties of small plates $9 \mathrm{~mm}$ thick and as rolled in laboratory (Stecls in Table 1) 


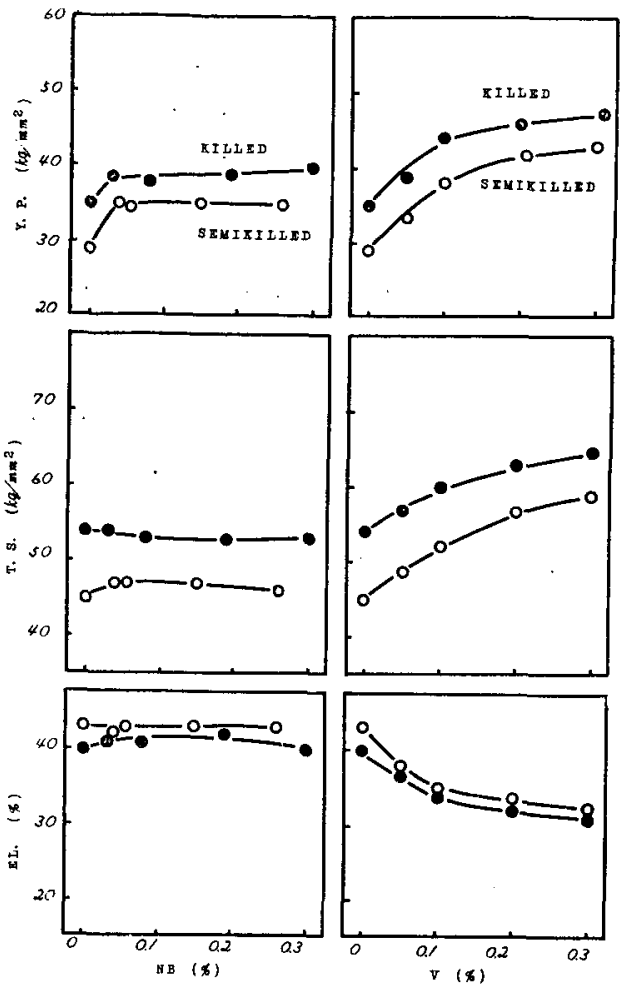

Fig. 3 Comparision between effect of niobium and vanadium addition on tensile properties of small plates $13 \mathrm{~mm}$ thick and normalized after rolling (Steels in Table 1)

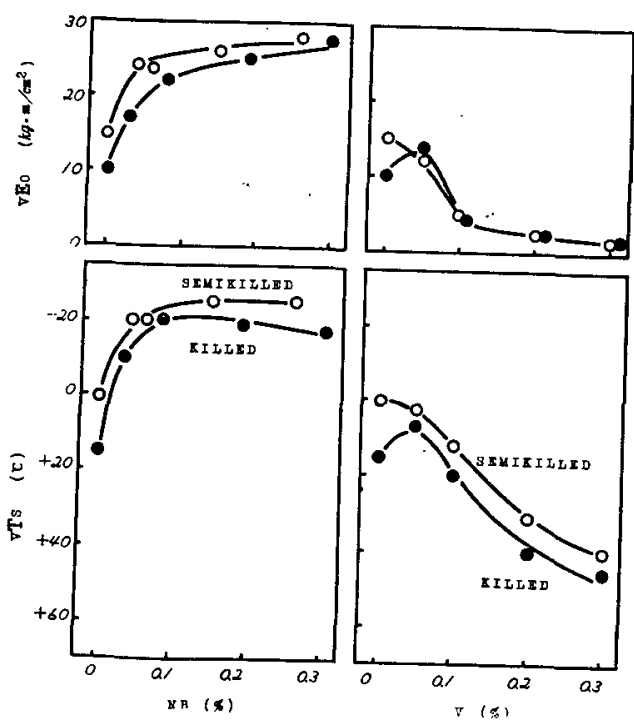

Fig. 4 Comparision between effect of niobium and vanadium addition on $2 \mathrm{~mm} \mathrm{~V}$-notch Charpy impact properties of small plates $13 \mathrm{~mm}$ thick and normalized after rolling (Steels in Table 1)
加させるためには，0.05\% 前後のVの添加の力が $\mathrm{Nb} の$ 場合より手衝撃性質の点で少し優れている，引張り強度 を $5 \sim 6 \mathrm{~kg} / \mathrm{mm}^{2}$ 程度增加させるだけでじゅう分な埸合 には，Vの使用が好ましい。

3）婔ならしを加えた状態では，Nbの方が引張り強 度の低下はむしろ大きい.しかし橴ならし後の引張り強 度上くに降伏点の同一レベルで比較すれば，その衝撃性 質は Nb の場合がVよりも優れている。

てのように Nbを派加するととによって死延のままの 銿板の引張り忩度が増加する現象は，すでにW.B. Morrison $^{5}$ も指摘しているように Nb の炭窒化物の析 出硬化作用によるものであるう。Vによる同㥞の効果も おなじくおあにその炭窒化物の析出作用によるあのよ考 えられる。また上記の（3）貢の現象は，䙳ならし温度 においては $\mathrm{Nb}$ は此較的大型の炭窒化物の形でほとんご 析出し，析出硬化作用を失ない，結鼠粒微細化の効果の みを残すのに刘して，Vの場合にはその炭窒化物の析出 温度の中心が焼ならし温度より毛低いよころにあるため に，㜔ならし姏理をうけてあ析出硬化の作用がなお失な われないためと考えられる。

Table 2 の小鋼塊による奏験の結果を Fig. 5, 6 およ び Photo. 1 に示す. Fig. 5 は圧延のままの板厚 9 , 13および $25 \mathrm{~mm}$ の小鋼板の降伏点, 引張り虫さ，仰び および衝撃試験值におよばす $\mathrm{Nb} の$ 極少量添加の效果を
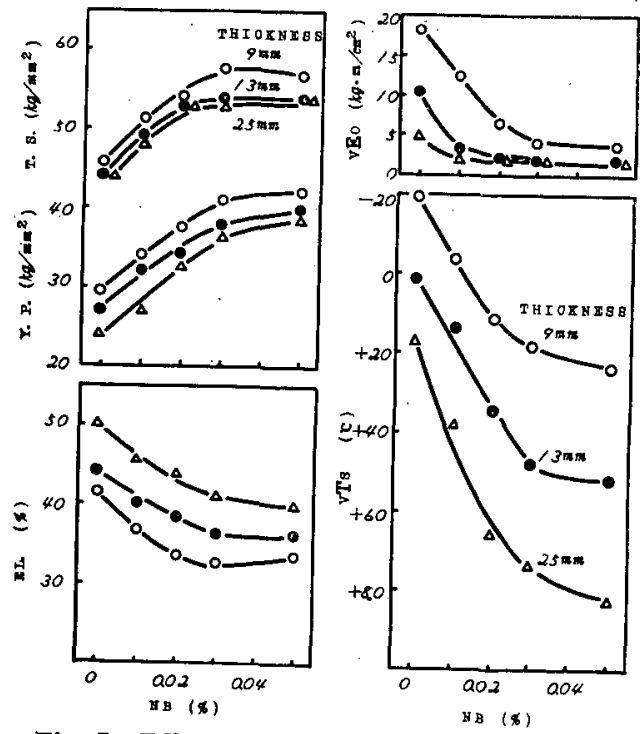

Fig. 5 Effect of small amount of niobium and thickness of plate on tensile and $2 \mathrm{~mm}$ $V$-notch Charpy impact properties of small plates as rolled in laboratory (Steels in Table 2 and thickness of plates 9,13 and $25 \mathrm{~mm}$ ) 


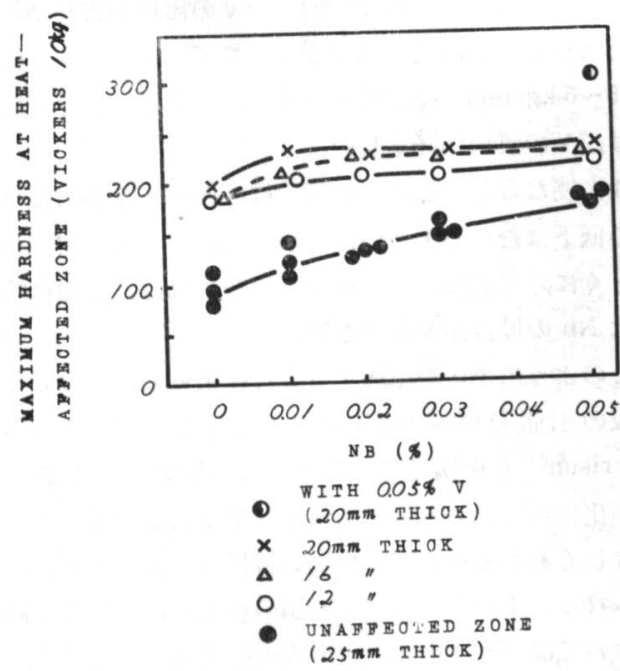

Fig. 6 Effect of small amount of niobium on maximum hardness at heat-affected zone and unaffected of small plates (Steels in Table 2 and Fig. 5)

a

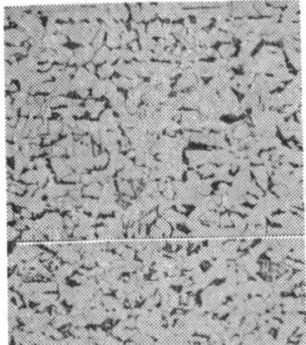

b

d

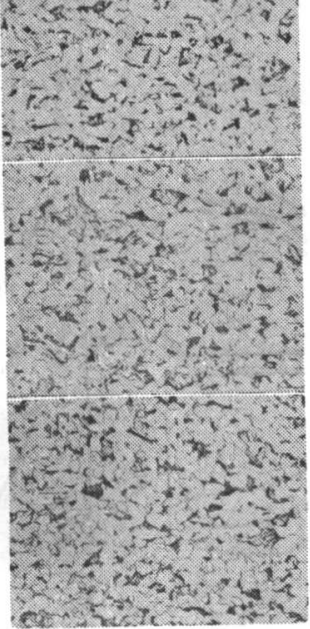

Photo. 1 Micro-structure of small steel plates containing different amount of niobium, $9 \mathrm{~mm}$ thick and as rolled in laboratory (Steels in Table 2 and Fig. 5)

Photo. a: Nb $0.00 \%$ (Steel Nb 9), Photo. b: $\mathrm{Nb} 0.01 \%$ (Steel Nb 10), Photo. c: Nb 0.02\% (Steel Nb 11), Photo. d: Nb 0.103\% (Steel Nb 12)
示しており，板厚の影響もみるてとができる. Fig. 6 は溶接熱影響部最高硬度試験の結果であり, Photo. 1 はミクロ組織を示す.乙れらの結果からつぎのことがわ かる。

1) $\mathrm{Nb}$ はその量がおよそ $0.03 \%$ まではほぼ直線状に 降伏点および引張り強さを増加させるが, それを超える と飽和する傾向がみられる. 衝撃性質むそれに対応して 変化しているようである.

2) このような引張り強度の増加の傾向は, 板厚 25 $\mathrm{mm}$ の場合であ板厚 $9 \mathrm{~mm}$ の場合と差が認められず, 同程度の引張り強度の増加が期待できる.

3）圧延のままの鋼板のフェライト結晶粒は $\mathrm{Nb}$ を添 加するとわずかに微細化する傾向が認められる. またパ ーライト組織の一部にベーナイト化の傾向がみられる. これはオーステナイトに固溶している $\mathrm{Nb}$ がその変態を 遅くする作用によるものと考えられるが， Nb の添加に よる引張り強度の増加には, さきにのべた析出硬化作用 のほかにとのような組織の変化も原因しているむのと思 われる.

4) $\mathrm{Nb}$ を添加すると溶接熱影響部最高硬度は母材の 硬度増加とともに多少増加するが，母材硬度との差で表 わされる硬化量には， $\mathrm{Nb}$ の量が増すとかえって減少す る傾向がみとめられる.

なお溶接性試験としててのほかにスリット形割れ試験 あ行なったが，いずれの鋼板にも割れはまったく発生し なかった。

\section{3. $\mathrm{Nb}$ 添加低炭素鋼板の機械的性 質におよほす熱間圧延条件の影}

熱間圧延のままの状態の鋁板の機械的性質にその圧延 条件が大きい影響をおよぼすととはいうまですない、鋼 板にじゅう分な靶性を与えるためには，一般にできるだ け低い温度で強い圧下を加えて圧延し，圧延後には適当 な速度で泠却して組織を微細にしなければならない. $\mathrm{Nb}$ 添加鋼板の場合もあちろんその例外ではないであろ うが，高い引張り強度に対応して䩡性はかなり失なわれ る傾向にあるために, 圧延温度および圧延後の泠却速度 などを十分管理して組織の微細化をはかることが一層重 要であると考えられる．乙こでは圧延条件の中であすっ とも重要と考えられる圧延温度とくに最終圧延温度の影 響について明らかにするために，小型压延機を使用して 小鋼板による実験を行なった。

なお熱間圧延後ただちにコイル状に巻きとられるコイ ル状鋼板では，巻きとられた温度から徐冷される焼なま し処理をうける. この焼なまし処理によってパーライト 
組織が球状化するほどの影響をうけると，一般に引張り 強度はかなり低下し，いっぱう衝揧性質は向上する現象 がみられる. $\mathrm{Nb}$ を添加した碙板では $\mathrm{Nb}$ の炭空化物の 析出硬化のために，パーライトが球状化してあ引張り強 度の但下はそれほよ゙大きくなく，いっぽう衝撃性質はか なり向上する．乙の現象は $\mathrm{Nb}$ 添加鋼によるコイル状鋼 板の 1 つの特性之考えられる。

\section{1 実験方法}

板厚 $32 \mathrm{~mm}$ の鋼板を素材として, $1200^{\circ} \mathrm{C}$ に加熱し, ついで小型圧延機で板厚 $13 \mathrm{~mm}$ の小鋼板（板巾 150 $\mathrm{mm}$, 板長 $600 \mathrm{~mm}$ ) 飞圧延した。压延前の加熱温度む軎 要であり，一般にその温度が低いほど組織の微細化に有 効であるが，能率のよい压延作業を行なうには $1200^{\circ} \mathrm{C}$ 前後の加熱は必要である.

Table 3 に供試材の成分組成を示す. $\mathrm{Nb}$ を源加して いない銅板 Dを比較のために使用した、最終生延温度は $650 \sim 1000^{\circ} \mathrm{C}$ の籁目をおよそ $50^{\circ} \mathrm{C}$ の間隔で変え, パス 回数は目標の最終压延温度によって変わり，4〜11回で

Table 3 Chemical composition of steel plates used for study on hot-rolling temperature

\begin{tabular}{c|c|c|c|c|c|c|c}
\hline \hline Steel & $\mathrm{C} \%$ & $\mathrm{Si} \%$ & $\mathrm{Mn} \%$ & $\mathrm{P} \%$ & $\mathrm{~S} \%$ & $\mathrm{Cu} \%$ & $\mathrm{Nb} \%$ \\
\hline $\mathrm{C}$ & 0.15 & 0.45 & 1.37 & 0.018 & 0.026 & 0.07 & 0.03 \\
$\mathrm{D}$ & 0.15 & 0.37 & 1.28 & 0.015 & 0.021 & 0.10 & - \\
\hline
\end{tabular}

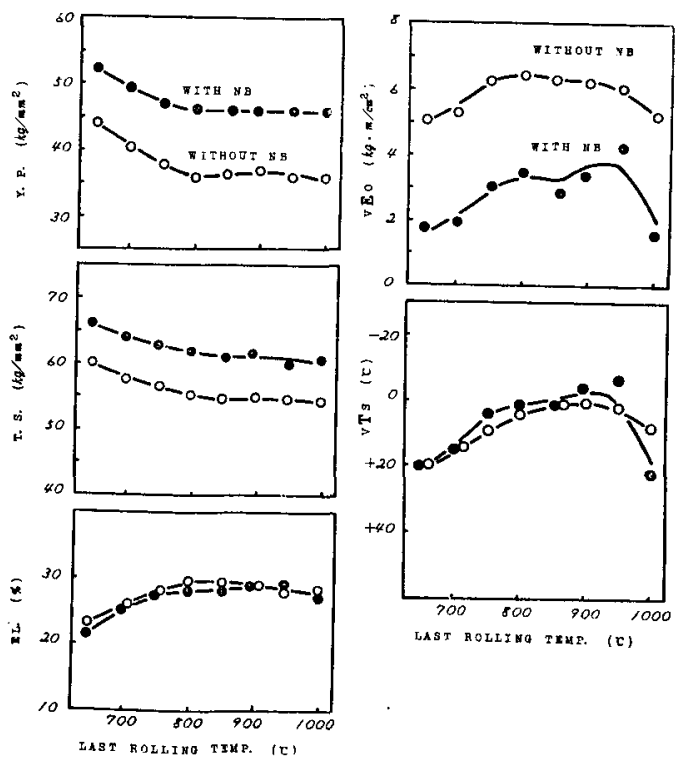

Fig. 7 Effect of last rolling temperature on tensile and $2 \mathrm{~mm} V$-notch Charpy impact properties of small plates as rolled in laboratory (Steels in Table 3 , heating temperature $1200^{\circ} \mathrm{C}$ and thickness reduction from 32 to $13 \mathrm{~mm}$ )
瓜延を終了した。

\section{2 実験結果}

Fig. 7 に降伏点, 引張り強さ, 伸びおよび衝揧值に およぼす最終圧延温度の影響を示す。

$\mathrm{Nb}$ を涯加してもとくに変った傾向はみられない，Nb の有無にかかわらず，最終王脠温度がおよそ $700^{\circ} \mathrm{C}$ を 下ると冷間加工による硬化が残り，引張り強度は增加 し，伸びおよび衙㧘性質は低下する。いっぽうおよそ $1000^{\circ} \mathrm{C}$ をこえると組織が粗大化するために，衝撃性質 の低下が明瞭に譛められるようになる．750 950 ${ }^{\circ} \mathrm{C} の$ 符囲では機械的性質に大きな変化は認められないこと屯 わかる。

以上小型圧延機を使用して，熱間圧延のままの小鐥板 について行なった実験の結果についてのべたが，その引 張り試験の值では工場で造られる大鋼板の成績と比較的 よく一致したあのの, 衝揧試験の值ではかなりの差が認 められる場合が多かった。圧延条件が完全に再現されて いないためであるが，たとえば最終圧延温度の影響につ いて工場で大鋼板による調查を行なった絬果では, 750 〜950 ${ }^{\circ} \mathrm{C}$ の簌囲ですその温度が低い力が衝撃性質の点で 瀀れていた.しかしおよその傾向を知り予借的な知識を うるにはじゅう分役立つものであった。

\section{4. $\mathrm{Nb}$ 添加高張力鋼板の性質の特徴}

以上の小鋼板による害験の結果から，低炭素鋼に Nb を $0.05 \%$ 程度まで添加することによって熱間圧延のまま の銅板の引張り強度をVの場合よりはいちじるしく向上 させることができるとと，そのとき衙揧性質はかなり低 下するが，溶接熱影響部の硬化なぞ溶接性には悪影響の ないことが明らかとなったが，以下工場で圧延した大鋼 板の成績について紹介し，その性質の特徴について考察 する.

熱間圧延のままの鐥板の引張り強度を増加して60キロ 級の高張力鋼板を造るためには, むちろん鋼板の C, $\mathrm{Si}, \mathrm{Mn}$ さらにその他の合金元素を堌加させる方法むあ るが，造埸性や成品の性質上扔のずから限度があるとと はいうまであない，従来わが国では㜔入れ烧もよ゙しある いは焼ならし燒すどしの䓡処理を加えたいわゆる調質型 の60キロ級の高張力鉵板が溶接構造用としてもっぱら用 いられている. Nb を少量従来の50キ口級の高張力䤱に 添加することによって，われわれははじめて低炭菜鋼で しかもフェライトとパーライト組織の60キ口級高張力鋼 板をむつことができたということができよう。

\section{1 成分組成}

従来の50キロ級の銅板に使用されてきた低炭素低マン ガンアルミキルド鋼に Nb を添加した60キロ級の鋼板の 
Table 4 Chemical composition of large plates rolled in works (low carbon and low manganese killed steel)

\begin{tabular}{c|c|c|c|c|c|c|c|c|c|c|c|c|c|c}
\hline \hline Steel & $\begin{array}{c}\text { Thickness (shape) } \\
\mathrm{mm}\end{array}$ & $\mathrm{C} \%$ & $\mathrm{Si} \%$ & $\mathrm{Mn} \%$ & $\mathrm{P} \%$ & $\mathrm{~S} \%$ & $\mathrm{Cu} \%$ & $\mathrm{Sol} . \mathrm{Al} \%$ & $\mathrm{Nb} \%$ \\
\hline 1 & $\begin{array}{c}6,12 \text { (plate) } \\
6.4 \text { (coi1) }\end{array}$ & 0.16 & 0.29 & 1.29 & 0.021 & 0.018 & 0.11 & 0.019 & 0.035 \\
\hline$\|$ & 20,32 (plate) & 0.16 & 0.42 & 1.43 & 0.024 & 0.022 & 0.06 & 0.018 & 0.051 \\
\hline
\end{tabular}

Table 5 Chemical composition of large plates rolled in works (low carbon semikilled steel)

\begin{tabular}{|c|c|c|c|c|c|c|c|c|}
\hline Steel & $\begin{array}{c}\text { Thickness (shape) } \\
\text { mm }\end{array}$ & $\mathrm{c \%}$ & $\mathrm{Si} \%$ & $\mathrm{Mn} \%$ & $\mathrm{P} \%$ & $\mathrm{~s} \%$ & $\mathrm{Cu} \%$ & $\mathrm{Nb} \%$ \\
\hline 正 & $6.3(\operatorname{coil})$ & 0.16 & 0.06 & 0.49 & 0.014 & 0.019 & 0.05 & 0.03 \\
\hline N & $4.7(\operatorname{coil})$ & 0.16 & 0.04 & 0.95 & 0.014 & 0,022 & 0.07 & 0.03 \\
\hline V & 4.7 (coil) & 0.13 & 0.05 & 0.91 & 0.015 & 0.024 & 0.07 & 0.03 \\
\hline $\mathrm{V}$ & $12,20,32$ (plate) & 0.15 & 0.03 & 1.29 & 0.017 & 0.017 & 0.07 & 0.04 \\
\hline
\end{tabular}

Table 6 Chemical composition of large plates rolled in works (low carbon low alloy killed steel)

\begin{tabular}{c|c|c|c|c|c|c|c|c|c|c|c|c|c}
\hline Steel & $\begin{array}{c}\text { Thickness (shape) } \\
\mathrm{mm}\end{array}$ & $\mathrm{C} \%$ & $\mathrm{Si} \%$ & $\mathrm{Mn} \%$ & $\mathrm{P} \%$ & $\mathrm{~S} \%$ & $\mathrm{Cu} \%$ & $\mathrm{Cr} \%$ & $\mathrm{Ni} \%$ & $\begin{array}{c}\text { Sol. Al } \\
\%\end{array}$ & $\mathrm{Nb} \%$ & $\mathrm{~V} \%$ \\
\hline $\mathrm{VW}$ & 9 (coil) & 0.10 & 0.29 & 1.27 & 0.014 & 0.014 & 0.48 & 0.30 & 0.52 & 0.015 & 0.04 & 0.05 \\
\hline
\end{tabular}

Table 7 Tensile and bending properties of large plates rolled of low carbon and low manganese killed steels as shown in Table 4

\begin{tabular}{|c|c|c|c|c|c|c|}
\hline Steel & $\begin{array}{c}\text { Thickness (shape) } \\
\mathrm{mm}\end{array}$ & $\begin{array}{c}\text { Heat } \\
\text { treatment }\end{array}$ & $\begin{array}{l}\text { Y.P. (ratio) } \\
\mathrm{kg} / \mathrm{mm}^{2}(\%)\end{array}$ & $\begin{array}{c}\mathrm{T} . \mathrm{S} . \\
\mathrm{kg} / \mathrm{mm} 2\end{array}$ & E1. (G.L. & $\begin{array}{l}\text { Bending } \\
(\mathrm{R}: 1.5 \mathrm{t})\end{array}$ \\
\hline I & $\begin{array}{c}6 \quad \text { (plate) } \\
6.4 \text { (coil)* } \\
12 \quad \text { (plate) }\end{array}$ & $\begin{array}{c}\text { As rolled } \\
" \\
" 1\end{array}$ & $\begin{array}{l}52(79) \\
50(79) \\
49(79)\end{array}$ & $\begin{array}{l}66 \\
63 \\
62\end{array}$ & $\begin{array}{l}28 \\
29 \\
33\end{array}$ & $\begin{array}{c}\text { Good } \\
" 1 \\
"\end{array}$ \\
\hline 1 & $\begin{array}{ll}20 & (" \prime) \\
32 & (" \prime)\end{array}$ & $"$ & $\begin{array}{l}48(77) \\
44(75)\end{array}$ & $\begin{array}{l}62 \\
59\end{array}$ & $\begin{array}{l}36 \\
32\end{array}$ & $"$ \\
\hline I & $\begin{array}{c}6 \quad \text { (plate) } \\
5.4 \text { (coil)* } \\
12 \text { (plate) }\end{array}$ & $\begin{array}{c}\text { Normalized** } \\
" \prime \\
"\end{array}$ & $\begin{array}{l}43(78) \\
43(77) \\
42(75)\end{array}$ & $\begin{array}{l}55 \\
56 \\
56\end{array}$ & $\begin{array}{l}34 \\
37 \\
41\end{array}$ & $\begin{array}{c}\text { Good } \\
\quad " \\
\prime \prime\end{array}$ \\
\hline
\end{tabular}

*) Width : $960 \mathrm{~mm}$, Width of other plate : $1,524 \mathrm{~mm}$

**) Heating at $880^{\circ} \mathrm{C}$ for 1 hour followed by air-cooling

Table 8 Tensile and bending properties of large plates rolled of low carbon semikilled steels as shown in Table 5

\begin{tabular}{|c|c|c|c|c|c|c|}
\hline Steel & Thickness (shape) & $\underset{\text { Heat }}{\text { treatment }}$ & $\begin{array}{l}\text { Y.P. (ratio) } \\
\mathbf{k g} / \mathbf{m m}^{2}(\%)\end{array}$ & $\underset{\mathrm{kg} / \mathrm{mm}^{2}}{\mathrm{~T} . \mathrm{S}}$ & El. (G.L. $50 \mathrm{~mm})$ & $\begin{array}{l}\text { Bending } \\
(\mathrm{R}: 1.0 \mathrm{t})\end{array}$ \\
\hline II & 6.3 (coil) & As rolled & $44(80)$ & 55 & 32 & Good \\
\hline IV & $4.7(" 1)$ & $" \prime$ & $51(86)$ & 59 & 28 & " \\
\hline V & $4.7(" \prime)$ & $"$ & $47(84)$ & 56 & 29 & $"$ \\
\hline V & $\begin{array}{ll}12 & \text { (plate) } \\
20 & (" \prime) \\
32 & (" \prime)\end{array}$ & $\begin{array}{l}" \prime \\
" \prime\end{array}$ & $\begin{array}{l}48(83) \\
42^{2}(77) \\
41(75)\end{array}$ & $\begin{array}{l}58 \\
56 \\
55\end{array}$ & $\begin{array}{l}33 \\
32 \\
32\end{array}$ & $\begin{array}{l}" \prime \\
" \prime\end{array}$ \\
\hline
\end{tabular}

Width : $960 \mathrm{~mm}$ in coil and $1,524 \mathrm{~mm}$ in plate 
化学成分を Table 4 K，41キロ級の低炭素セミキルド 鋼に Nbを添加した米国型ともいうべき50キロもしくは 55 キロ級の鍶板の化学成分を Table 5 亿示す. Nb の添 加量はさきの実験結果にしたがって0.03〜0.05\%とした。 なお Table 6 はCをとくに低くして $\mathrm{Si}, \mathrm{Mn}, \mathrm{Nb} の$ ほ加に Cu, Cr, Ni，Vを少量ずつ添加した低合金䤱で ある. Table 4 の Nb 添扣低マンガン鏎によるよりは 引張り強度が高く，しかも衝慗性質の点で劣ることのな。 いととを目標に選定した鋼種である.焼ならし処理を加 えて使用されるわが国最初の60キ口級高張力鋼板である 日本造船研觉協会の溶接艦船用60キ口高張力鋼板規格案 をはじめとする諸研究6,7 および溶接㙝会における最近 の原子炉用高張力銅板の研究8)を参考にした。 また耐候 性鋼板の最近の成績も参考にし，とれに上記の実験結果 や実験計画法による研究の成果 ${ }^{9)}$ もお放せて検討して撰 んだ.

\section{2 一般の機械的性質}

Table 4 および 5 の $\mathrm{Nb}$ 添加低炭素鉶による王延の ままの鐥板の引張りおよび曲げ試験の成續を Table 7 および 8 括シャルピ一衝整試験の成績を Table 9 お よび10に示す.

Table 7 においては, 板愿が $20 \mathrm{~mm}$ までの鋼板は降 伏点および引張り強さともに溶接協会の溶接棈造用高張 力鎆板規格 (WES-135) の HW 45 の規格犆 (降伏点 $45 \mathrm{~kg} / \mathrm{mm}^{2}$ 以上, 引張り強さ $60 \sim 72 \mathrm{~kg} / \mathrm{mm}^{2}$ ) 飞合格 している. いっぽう米国石油協会 (API) の $5 \mathrm{~L} \times 60$ の
降状点の下限は $42.2 \mathrm{~kg} / \mathrm{mm}^{2}$ であるからこれにあ合格 していることになる。とのように従来の50キロ級の低マ ンガン鈵に少量の $\mathrm{Nb}$ を添加していわゆる60キロ級の鋼 板を造ることができる。

Table 8 においては, 板厚が $32 \mathrm{~mm}$ までの鋼板は WES の HW 36 (降伏点 $36 \mathrm{~kg} / \mathrm{mm}^{2}$ 以上, 引張り強 さ $53 \sim 65 \mathrm{~kg} / \mathrm{mm}^{2}$ ) 飞相当し，乙のうち板厚 $12 \mathrm{~mm}$ まではWES の HW 40 (降伏点 $40 \mathrm{~kg} / \mathrm{mm}^{2}$ 义上, 引 張り強さ $57 \sim 70 \mathrm{~kg} / \mathrm{mm}^{2}$ ) に相当している．とのよう に従来の41キロ級の低炭素セミキルド鋼に Nb 老少量添 加するととによっていわゆる55キロ級の銅炍をつくると とができる.

なお Table 7 には, 焼ならし処理 $\left(880^{\circ} \mathrm{C}\right.$ に 1 時間 加㷫後空冷）を加えたときの引張り強度も示している が，降伏点执よび引張り強さとむにかなり低下すること がおかる．㛙ならしを加えるとAl の場合とおなじく $\mathrm{Nb}$ による細粒化の効果が現われて，烛ならし後もその 降伏此は高いままで保持されているが，乙の点羊 $\mathrm{Nb}$ 含有しない鋼板の場合と相異している。

Table 9 には 60 キロ鋼板のシャルピー衝整試験成績 を示しているが，とくに破面遷移温度はこれまで低マン ガン鋼で造ってきた50キロ級の鋼板のそれよりもすぐれ ているはどである。あっとも吸収エネルギーの值は全般 に低く，とくに压延方向に跙角な $\mathrm{T}$ 方向の $\mathrm{vT}_{10}$ や ${ }_{5} \mathrm{U}^{\mathrm{T}} \mathrm{T}_{1.0}$ の低エネルギー遷移温度が板厚が薄い場合には 高温例にきている.したがって $\mathrm{vT}_{10} や{ }_{5} \mathrm{~T}_{1.0}$ の方が

Table 9 Charpy impact properties of large plates rolled of low carbon and low manganese killed steels as shown in Table 4 and 7

\begin{tabular}{|c|c|c|c|c|c|c|c|c|c|}
\hline Steel & $\begin{array}{c}\text { Thickness (shape) } \\
\text { mm }\end{array}$ & $\begin{array}{c}\text { Direction } \\
\text { of } \\
\text { sampling }\end{array}$ & $\cdot{ }^{\circ} \mathbf{T}_{\mathbf{4}} \mathbf{C} 8$ & $\begin{array}{c}\mathrm{vE}_{0} \\
\mathrm{~kg}-\mathrm{m} / \mathrm{cm} 2\end{array}$ & $\mid \mathrm{vT}_{10}$ or $15 \mid$ & $5 \mathrm{U} T_{1.0}{ }_{\circ}^{\circ} \mathrm{Cr} 1.4$ & ${ }^{\mathrm{V}} \mathbf{T}_{\mathbf{C}}$ & $\begin{array}{l}v T s \\
{ }^{\circ} \mathrm{C}\end{array}$ & ${ }^{\circ} T_{\mathrm{C}}$ \\
\hline \multirow{3}{*}{1} & 6 (plate) & $\begin{array}{l}\mathrm{L} \\
\mathrm{T}\end{array}$ & $\begin{array}{r}0 \\
-\end{array}$ & $\begin{array}{r}12.0 \\
3.5\end{array}$ & $\begin{array}{r}-83 \\
-40 \\
\end{array}$ & $\begin{array}{r}<-120 \\
+60 \\
\end{array}$ & $\begin{array}{r}-70 \\
-100 \\
\end{array}$ & $\begin{array}{r}-75 \\
-90 \\
\end{array}$ & $\begin{array}{l}-35 \\
-40 \\
\end{array}$ \\
\hline & 6.4 (coil) & $\begin{array}{l}\mathbf{L} \\
\mathbf{T}\end{array}$ & $\begin{array}{r}+30 \\
-\end{array}$ & $\begin{array}{r}10.5 \\
3.3\end{array}$ & $\begin{array}{r}-115 \\
>+60\end{array}$ & $\begin{array}{l}<-120 \\
>+100\end{array}$ & $\begin{array}{r}-120 \\
-120 \\
\end{array}$ & $\begin{array}{l}<-120 \\
<-120\end{array}$ & $\begin{array}{l}-85 \\
-90 \\
\end{array}$ \\
\hline & 12 (plate) & $\begin{array}{l}\mathbf{L} \\
\mathrm{T}\end{array}$ & $\begin{array}{r}-35 \\
- \\
\end{array}$ & $\begin{array}{r}13.3 \\
3.6\end{array}$ & $\begin{array}{l}-45 \\
-40 \\
\end{array}$ & $\begin{array}{r}-90 \\
-65 \\
\end{array}$ & $\begin{array}{r}-30 \\
-50 \\
\end{array}$ & $\begin{array}{r}-30 \\
-50 \\
\end{array}$ & $\begin{array}{r}+5 \\
0 \\
\end{array}$ \\
\hline \multirow{2}{*}{ 】 } & $20("))$ & $\begin{array}{l}\mathbf{L} \\
\mathbf{T}\end{array}$ & $\begin{array}{r}-46 \\
-\end{array}$ & $\begin{array}{r}13.5 \\
5.0\end{array}$ & $\begin{array}{r}-65 \\
-50 \\
\end{array}$ & - & $\begin{array}{r}-45 \\
-52 \\
\end{array}$ & $\begin{array}{r}-55 \\
-49 \\
\end{array}$ & $\begin{array}{r}-30 \\
-47 \\
\end{array}$ \\
\hline & $32(" n)$ & $\begin{array}{l}\mathbf{L} \\
\mathbf{T}\end{array}$ & $\begin{array}{r}-25 \\
+20 \\
\end{array}$ & $\begin{array}{r}12.8 \\
5.1 \\
\end{array}$ & $\begin{array}{r}-45 \\
-40 \\
\end{array}$ & - & $\begin{array}{l}-20 \\
-32 \\
\end{array}$ & $\begin{array}{l}-22 \\
-18 \\
\end{array}$ & $\begin{array}{r}-5 \\
-17 \\
\end{array}$ \\
\hline
\end{tabular}

Heat treatment : As rolled

$\mathrm{vT}_{4.8}:$ Temperature at $4.8 \mathrm{~kg}-\mathrm{m}$, using specimen with milled $\mathrm{V}$-notch $2 \mathrm{~mm}$ deep

${ }^{v} \mathbf{T}_{10}$ or 15 : Temperature at 10 or $15 \mathrm{ft}-1 \mathrm{~b}$,

$v_{10}$ for plates 6 and $6.4 \mathrm{~mm}$ thick (size of specimen :5 $\times 10 \times 55 \mathrm{~mm}$ ),

$v^{\top} T_{15}$ for other plates (size of specimen: $10 \times 10 \times 55 \mathrm{~mm}$ )

${ }_{5} \mathrm{UT}_{1.0}$ or 1.4 : Temperature at 1.0 or $1.4 \mathrm{~kg}-\mathrm{m}$, using specimen with milled U-notch $5 \mathrm{~mm}$ deep,

${ }_{5} \mathrm{UT}_{1.0}$ for plates 6 and $6.4 \mathrm{~mm}$ thick (size of specimen : $5 \times 10 \times 55 \mathrm{~mm}$ ),

${ }_{5} \mathrm{U}_{1.4}$ for other plates (size of specimen : $10 \times 10 \times 55 \mathrm{~mm}$ )

VTE : Temperature at a half of maximum absorbed energy

p'Ts : Temperature at $50 \%$ brittle fracture surface, using specimen with pressed V-notch $2 \mathrm{~mm}$ deep 
Table 10 Charpy impact properties of large plates rolled of low carbon semikilled steels as shown in Table 5 and 8

\begin{tabular}{|c|c|c|c|c|c|c|c|c|c|}
\hline Steel & $\begin{array}{c}\text { Thickness (shape) } \\
\mathrm{mm}\end{array}$ & $\begin{array}{c}\text { Direction } \\
\text { of } \\
\text { sampling }\end{array}$ & $\mathrm{v}_{{ }^{\circ} \mathrm{C}} \mathbf{C}$ & $\underset{\mathrm{v} \mathbf{E}_{0}}{\mathrm{~kg}-\mathrm{m} / \mathrm{cm} 2}$ & $v T_{9.6 \sim 15}$ & $\mathbf{s u}^{\mathrm{T}} \mathrm{T}_{0.9} \sim 1.4$ & ${ }_{{ }^{\circ} \mathrm{C}}^{\mathrm{V}}$ & ${ }_{{ }^{\circ} \mathrm{C}} \mathrm{T}_{\mathrm{S}}$ & ${ }_{{ }^{\circ} \mathrm{C}}^{\mathrm{T}}$ \\
\hline III & 6.3 (coil) & L & +20 & 9.7 & -30 & -75 & -25 & -20 & 0 \\
\hline Iil & $0.3(\mathrm{COII})$ & $\mathrm{T}$ & - & 4.8 & -10 & -40 & -20 & -25 & +5 \\
\hline $\mathrm{N}$ & 4.7 (coil) & $\mathbf{L}$ & - & 11.3 & -65 & $<-100$ & -55 & -60 & -20 \\
\hline N & & $\mathbf{T}$ & - & 5.9 & -30 & -50 & -35 & -45 & -25 \\
\hline $\mathrm{V}$ & 4.7 (coil) & $L$ & - & 11.8 & -80 & $<-100$ & -70 & -80 & -50 \\
\hline$V$ & 4.7 (con) & $\mathrm{T}$ & - & 4.7 & -50 & $>+40$ & -65 & -75 & -50 \\
\hline \multirow{6}{*}{$\mathrm{Vl}$} & 12 (olate) & L & -30 & 13.1 & -20 & - & -15 & -20 & +5 \\
\hline & 12 (plate) & $\mathrm{T}$ & - & 3.2 & -10 & - & -17 & -8 & +12 \\
\hline & \multirow{2}{*}{$20(" \prime)$} & $\mathrm{L}$ & -37 & 16.6 & -50 & - & -27 & -33 & - \\
\hline & & $\mathbf{T}$ & +10 & 4.3 & -40 & - & -30 & -26 & - \\
\hline & \multirow{2}{*}{$32(" n)$} & $\mathbf{L}$ & -5 & 5.3 & -25 & - & +2 & +2 & +20 \\
\hline & & $\mathbf{T}$ & +30 & 2.8 & -15 & - & -8 & +8 & +19 \\
\hline
\end{tabular}

\footnotetext{
Heat treatment: As rolled

$\mathrm{vT}_{9.6}$ and ${ }_{5} \mathrm{U} \mathrm{T}_{0.9}$ for plates $4.7 \mathrm{~mm}$ thick (size of specimen : $4 \times 10 \times 55 \mathrm{~mm}$ )

$\mathrm{vT}_{9.6}$ and $\mathrm{F}_{10}$ and ${ }_{5} \mathrm{U}_{1.0}$ for plates $6.3 \mathrm{~mm}$ thick (size of specimen : $5 \times 10 \times 55 \mathrm{~mm}$ )

$\mathrm{vT}_{15}$ and ${ }_{5} \mathrm{U}_{1.4}$ for plates more than $12 \mathrm{~mm}$ thick (size of specimen : $10 \times 10 \times 55 \mathrm{~mm}$ )
}

Table 11 Chemical composition and tensile properties of both plates with and without niobium (6.4 $\mathrm{mm}$ thick and as rolled in works on the same condition of rolling)

\begin{tabular}{|c|c|c|c|c|c|c|c|c|}
\hline Steel & $\underset{\text { Thickness (shape) }}{\text { mm }}$ & $\mathrm{C} \%$ & $\mathrm{Si} \%$ & $\mathrm{Mn} \%$ & $\mathrm{Nb} \%$ & $\begin{array}{l}\text { Y.P. (ratio) } \\
\mathrm{kg} / \mathrm{mm}^{2}(\%)\end{array}$ & $\underset{\mathrm{kg} / \mathrm{mm}^{2}}{\mathrm{~T} . \mathrm{S}}$ & E1. (G.L. $50 \mathrm{~mm})$ \\
\hline $\begin{array}{c}\text { With } \mathrm{Nb} \\
\text { Without } \mathrm{Nb}\end{array}$ & $6.4(\mathrm{coil})$ & $\begin{array}{l}0.20 \\
0.20\end{array}$ & $\begin{array}{l}0.04 \\
0.06\end{array}$ & $\begin{array}{l}0.51 \\
0.51\end{array}$ & $\begin{array}{c}0.048 \\
-\end{array}$ & $\begin{array}{l}43(77) \\
31(66)\end{array}$ & $\begin{array}{l}56 \\
47\end{array}$ & $\begin{array}{l}29 \\
36\end{array}$ \\
\hline
\end{tabular}

かえって V Ts や $\mathrm{P}_{\mathrm{S}}$ の破面遷移温度よりもかなり高 温例になるというような場合がみられ，6し溶接協会の 低温構造用鋼板判規準10)(低温棈造用鋼板材質判定基準 の旧案，1964年 3 月に改訂された）にしたがえば，その G種には不合格であるが，A種には合格するという一 般にはみられない性質を示すことになる。. Table 10 の 55キロ鋼板の薄板の場合にもおなじ傾向がみとめられ る.

また Table 9 において, 平板状の板厚 $6 \mathrm{~mm} \cdot$ の鋼 板とコイル状の板厚 $6.4 \mathrm{~mm}$ の鍋板と比較すれば, 後者 が $\mathrm{vT}_{\mathrm{S}}$ や $\mathrm{P}_{\mathrm{S}}$ の破面遷移温度および $\mathrm{v}_{\mathrm{E}}$ のエネル ギー遷移温度においてかなりすぐれているととがわか る. $600^{\circ} \mathrm{C}$ 以上の温度で巻きとられるために引張り強度 がわずかに低下しているが，衙撃性質の问上はそれだけ ではとうてい説明できないほどである。

このように Nb 添加鋼板の破面遷移温度がすぐれてい るのは、ミクロ組織の項でのべるように組織が微細化し ているためと考えられる、コイル状鋼板でとくに優れて いるのは高温で巻きとられたのち徐冷されるというよう な焼なましによる組織変化がそれに加わっているためで あろう。

$\mathrm{Nb}$ を添加していない低引張り強度の鋼板の成績と正
確に比較するために、,Table 5 のなかの鉹而とほとんど おなじ成分組成で，ただ $\mathrm{Nb}$ を添加していない鋼勓をお なじ条件でおなじ寸法の鋼板に王延して比較した結果を Table 11 および12に示す.

Table 11 にその引張り試験成績を比較して示してい るが, $\mathrm{Nb}$ の 0.048\%の添加によって板厚 $6.4 \mathrm{~mm}$ の鈯 板の降伏点は执よそ $12 \mathrm{~kg} / \mathrm{mm}^{2}$, 引張り強さは招よそ $9 \mathrm{~kg} / \mathrm{mm}^{2}$ あ增加していることがわかる.したがって降 伏比む大きくなっている.

Table 12 にはそのシャルピー衝慗試験成績を示す. $\mathrm{Nb}$ を添加した錭板の方が $\mathrm{vE}_{0}$ の吸収エネルギー值は 多少少っているが、 v $\mathrm{T}_{\mathrm{S}}$ などの破面遷移温度および ${ }_{\mathrm{V}} \mathrm{T}_{\mathrm{E}}$ のエネルギー遷移温度はむしろ優れている. Nb の 添加によって引張り强度は $10 \mathrm{~kg} / \mathrm{mm}^{2}$ 程度本增加して いるにもかかわらず，衝撃性質はむしろ優れた傾向を示 すようである。

つぎに Table 6 のb 添加低合金䠞による在延のま まの鈴板の引張りおよび曲げ試験成績を Table 13 K， シャルピー衙撃試験成績を Table 14 亿示す.

板厚は $9 \mathrm{~mm}$ の埕合のみであるが, 引張り試験成縝 はWES $の$ HW 50 (降伏点 $50 \mathrm{~kg} / \mathrm{mm}^{2}$ 以上, 引張り 強さ $62 \sim 75 \mathrm{~kg} / \mathrm{mm}^{2}$ ) に相当している.ささに Table 
Table 12 Charpy impact properties of both plates with and without niobium as shown in Table 11

\begin{tabular}{|c|c|c|c|c|c|c|c|c|c|}
\hline Steel & $\begin{array}{c}\text { Thickness (shape) } \\
\mathrm{mm}\end{array}$ & $\begin{array}{c}\text { Direction } \\
\text { of } \\
\text { sampling }\end{array}$ & ${ }^{\mathrm{v}} \mathrm{T}_{\mathbf{4} . \mathrm{s}}$ & $\begin{array}{c}\mathrm{vE}_{0} \\
\mathrm{~kg}-\mathrm{m} / \mathrm{cm} 2\end{array}$ & ${ }_{{ }^{\circ} \mathrm{C}}^{\mathrm{vT}_{10}}$ & ${ }^{5 \mathrm{U}} \mathrm{OT}_{1.0}$ & ${ }_{{ }^{\circ} \mathrm{C}}^{\mathrm{v}}$ & ${ }_{{ }^{\circ} \mathrm{C}}^{\mathrm{T}}$ & ${ }^{\circ} T_{S}$ \\
\hline \multirow[t]{2}{*}{ With $\mathrm{Nb}$} & \multirow{4}{*}{6.4 (coil) } & $\mathbf{L}$ & - & 8.0 & -35 & -80 & -25 & -32 & -5 \\
\hline & & $\mathrm{T}$ & 一 & 4.0 & 0 & 0 & -30 & -22 & -5 \\
\hline \multirow[t]{2}{*}{ Without Nb } & & $\mathbf{L}$ & -5 & 12.0 & -30 & -60 & -15 & -15 & 0 \\
\hline & & $\mathrm{T}$ & - & 3.0 & +5 & -20 & 0 & +5 & +10 \\
\hline
\end{tabular}

Table 13 Tensile and bending properties of large plate rolled of low carbon and low alloy steel as shown in Table 6

\begin{tabular}{c|c|c|c|c|c|c}
\hline Steel & $\begin{array}{c}\text { Thickness (shape) } \\
\text { mm }\end{array}$ & $\begin{array}{c}\text { Heat } \\
\text { treatment }\end{array}$ & $\begin{array}{c}\text { Y.P. (ratio) } \\
\mathrm{kg} / \mathrm{mm} \text { (\%) }\end{array}$ & $\begin{array}{c}\text { T.S. } \\
\mathrm{kg} / \mathrm{mm} 2\end{array}$ & El. (G.L. $\begin{array}{c}50 \mathrm{~mm}) \\
\%\end{array}$ & $\begin{array}{c}\text { Bending } \\
(\mathrm{R}: 1.5 \mathrm{t})\end{array}$ \\
\hline VII & 9 (coil) & As rolled & $53(83)$ & 64 & 25 & Good \\
\hline
\end{tabular}

Width : $900 \mathrm{~mm}$

Table 14 Charpy impact properties of large plate rolled of low carbon and low alloy steel as shown in Table 6 and 13

\begin{tabular}{|c|c|c|c|c|c|c|c|c|}
\hline Steel & $\begin{array}{c}\text { Thickness (shape) } \\
\text { mm }\end{array}$ & $\begin{array}{l}\text { Direction } \\
\text { of } \\
\text { sampling }\end{array}$ & ${ }^{\mathrm{V}} \mathrm{T}_{\mathrm{C}} \mathrm{C}_{\mathrm{C}} \mathrm{B}$ & $\begin{array}{c}v E_{0} \\
\mathrm{~kg}-\mathrm{m} / \mathrm{cm} 2\end{array}$ & ${ }_{{ }^{\circ} \mathrm{C}}^{\mathrm{T}_{12.5}}$ & $\begin{array}{l}\mathrm{VT}^{\circ} \mathrm{T} \\
{ }^{\circ} \mathrm{C}\end{array}$ & $\begin{array}{l}\mathrm{vTS}_{\mathrm{s}} \\
{ }^{\circ} \mathrm{C}\end{array}$ & $\begin{array}{l}{ }^{p} T_{S} \\
{ }^{\circ} C\end{array}$ \\
\hline VII & 9 (coil) & $\begin{array}{l}\mathrm{L} \\
\mathrm{T}\end{array}$ & -78 & $\begin{array}{r}13.3 \\
3.2\end{array}$ & $\begin{array}{r}-120 \\
-30\end{array}$ & $\begin{array}{l}-72 \\
-68\end{array}$ & $\begin{array}{l}-82 \\
-78\end{array}$ & $\begin{array}{l}-60 \\
-56\end{array}$ \\
\hline
\end{tabular}

Size of specimen : $7.5 \times 10 \times 55 \mathrm{~mm}$

Table 15 Results of wedge impact test of killed steel plates as shown in Table 4, 7 and 9 , and critical temperature for sefety use calculated

\begin{tabular}{|c|c|c|c|c|c|c|}
\hline \multirow{2}{*}{ Steel } & \multirow{2}{*}{$\begin{array}{c}\text { Thickness (shape) } \\
\mathrm{mm}\end{array}$} & \multirow{2}{*}{$\begin{array}{c}\text { Direction } \\
\text { of } \\
\text { sampling }\end{array}$} & \multirow{2}{*}{$\begin{array}{l}\mathrm{T}_{50} \\
{ }^{\circ} \mathrm{C}\end{array}$} & \multirow{2}{*}{$\begin{array}{c}{ }^{1 / 2} \sigma_{y} \mathrm{~T}_{A G^{*}} \\
\text { from } \mathrm{T}_{50}{ }^{\circ} \mathrm{C}\end{array}$} & \multicolumn{2}{|c|}{$\begin{array}{l}\text { Critical temperature } \\
\text { from WES** }{ }^{\circ} \mathrm{C}\end{array}$} \\
\hline & & & & & $\begin{array}{c}\text { Grade } G \\
\left(25 \mathrm{~kg} / \mathrm{mm}^{2}\right)\end{array}$ & $\begin{array}{c}\text { Grade } A \\
\left(25 \mathrm{~kg} / \mathrm{mm}^{2}\right)\end{array}$ \\
\hline \multirow{4}{*}{ J } & \multirow{2}{*}{6 (plate) } & $\mathrm{L}$ & -55 & -21 & -60 & -35 \\
\hline & & $\mathrm{T}$ & -70 & -35 & -85 & -65 \\
\hline & \multirow{2}{*}{$12(" \prime)$} & L & -43 & -11 & -45 & -20 \\
\hline & & $T$ & -49 & -16 & -60 & -40 \\
\hline \multirow{4}{*}{ - } & \multirow{2}{*}{$20(" \prime)$} & L & -41 & -9 & -54 & -34 \\
\hline & & $T$ & -48 & -16 & -60 & -46 \\
\hline & \multirow{2}{*}{$32(" \prime)$} & L & -43 & -11 & $-27 * * *$ & $-1^{* * * *}$ \\
\hline & & $T$ & -48 & +2 & $-38 * * *$ & $-13 * * *$ \\
\hline
\end{tabular}

*) Critical temperature for safety use under a half of yield strength of plates, calculated from $T_{50}$ according to equation $\left(1 / 2 \sigma y T_{A G}=26.1+0.87 \times T_{50}\right)$

**) Critical te mperature calculated from $\mathrm{p} \mathrm{T}_{\mathrm{S}}$ or $\mathrm{V} \mathrm{T}_{\mathrm{E}}$ according to WES (Welding Engineering Standard proposed from Japan Welding Engineering Society)

***) Applied stress $20 \mathrm{~kg} / \mathrm{mm}^{2}$

7 および 8 そ示したような $\mathrm{Nb}$ 添加低マンガン鋼板の板 厚 $5 \sim 6 \mathrm{~mm}$ の引張り強度に相当しているが，衝慗性質 の方は試験片の寸法の差を考慮すれば低合金鋼の成績が かなり優れている。な API の $5 \mathrm{~L} \times 70$ (案) の降伏 点の下限は $49.3 \mathrm{~kg} / \mathrm{mm}^{2}$ であるが，この低合金鎆板は この種の溶接高張力銅管用の鋼板を第 1 の対称に試作し たものである。

\section{3 特殊な脆性破壊試験成績}

てれらの鋼板の衝撃性質をさらに明らかにするため に，プレスノッチクラックスターター試験 (Wedge impact 試験と屯いわれる ${ }^{11)}$ と2 2 重引張り試験 ${ }^{12)}$ の成 績をつぎに示す。

プレスノッチクラックスターター試験では, 脆性龟裂 の長さが $50 \mathrm{~mm}$ となる温度 $\mathrm{T}_{50}$ を测定して, その鋼 板の脆性破壊伝播特性を評価することが行なわれる。す なわち $\mathrm{T}_{50}$ から下式によって ${ }_{1 / 2 \sigma y} \mathrm{~T}_{\mathrm{AB}}$ (降伏点の $1 / 2$ の 応力下における温度勾配型 2 重引張り試験の龟裂停止温 度）を推定している。 $\left.{ }_{1 / 2} \sigma_{\mathrm{y}} \mathrm{T}_{\mathrm{AG}}=26.1+0.87 \times \mathrm{T}_{50}\left(r=0.974, \mathrm{~S}_{\mathrm{E}}=9.4^{\circ} \mathrm{C}\right)^{13}\right)$ Table 15 17 Kプレスノッチクラックスターター試 
Table 16 Results of wedge impact test of semikilled steel plates as shown in Table 5, 8 and 10 , and critical temperature for safety use calculated

\begin{tabular}{|c|c|c|c|c|c|c|}
\hline \multirow[b]{2}{*}{ Steel } & \multirow{2}{*}{$\begin{array}{c}\text { Thickness (shape) } \\
\text { mm }\end{array}$} & \multirow{2}{*}{$\begin{array}{c}\text { Direction } \\
\text { of } \\
\text { sampling }\end{array}$} & \multirow{2}{*}{$\begin{array}{l}\mathrm{T}_{50} \\
{ }^{\circ} \mathrm{C}\end{array}$} & \multirow{2}{*}{$\begin{array}{c}1 / 2 \sigma_{\mathbf{Y}} \mathrm{T}_{\mathrm{AG}} \\
\text { from } \mathrm{T}_{50}{ }^{\circ} \mathrm{C}\end{array}$} & \multicolumn{2}{|c|}{$\begin{array}{l}\text { Critical temperature } \\
\text { from WES }{ }^{\circ} \mathrm{C}\end{array}$} \\
\hline & & & & & $\begin{array}{c}\text { Grade } G \\
\left(20 \mathrm{~kg} / \mathrm{mm}^{2}\right)\end{array}$ & $\begin{array}{c}\text { Grade } A \\
\left(20 \mathrm{~kg} / \mathrm{mm}^{2}\right)\end{array}$ \\
\hline \multirow{2}{*}{ II } & \multirow{2}{*}{6.3 (coil) } & $\mathbf{L}$ & -25 & +4 & -30 & -10 \\
\hline & & $\mathbf{T}$ & +32 & -2 & -25 & -5 \\
\hline \multirow{2}{*}{$\mathbb{N}$} & \multirow{2}{*}{$4.7(" \prime)$} & L & -38 & -7 & -55 & -30 \\
\hline & & $\mathbf{T}$ & -45 & -13 & -40 & -15 \\
\hline \multirow{2}{*}{ V } & \multirow{2}{*}{$4.7(" \prime)$} & L & -58 & -24 & -65 & -40 \\
\hline & & $\mathrm{T}$ & -64 & -30 & -60 & -40 \\
\hline \multirow{6}{*}{ V] } & \multirow{2}{*}{12 (plate) } & L & -7 & +20 & -34 & -6 \\
\hline & & $\mathrm{T}$ & -8 & +19 & -40 & -12 \\
\hline & \multirow{2}{*}{$20(" \prime)$} & $\bar{L}$ & - & - & -46 & -22 \\
\hline & & $\mathbf{T}$ & - & - & -46 & -22 \\
\hline & \multirow{2}{*}{$32(" \prime)$} & $\mathrm{L}$ & -16 & +12 & -14 & +12 \\
\hline & & $\mathbf{T}$ & -13 & +15 & -22 & +4 \\
\hline
\end{tabular}

Table 17 Results of wedge impact test of low alloy steel plate as shown in Table 6, 13 and 14 , and critical temperature for safety use calculated

\begin{tabular}{|c|c|c|c|c|c|c|}
\hline \multirow[b]{2}{*}{$\begin{array}{c}\text { Steel } \\
:\end{array}$} & \multirow{2}{*}{$\begin{array}{c}\text { Thickness (shape) } \\
\mathrm{mm}\end{array}$} & \multirow{2}{*}{$\begin{array}{l}\text { Direction } \\
\text { of } \\
\text { sampling }\end{array}$} & \multirow{2}{*}{$\begin{array}{l}\mathrm{T}_{50} \\
{ }^{\circ} \mathrm{C}\end{array}$} & \multirow{2}{*}{$\begin{array}{c}1 / 2 \sigma y \mathrm{~T}_{\mathrm{AG}} \\
\text { from } \mathrm{T}_{50}{ }^{\circ} \mathrm{C}\end{array}$} & \multicolumn{2}{|c|}{$\begin{array}{l}\text { Critical temperature } \\
\text { from WES }{ }^{\circ} \mathrm{C}\end{array}$} \\
\hline & & & & & $\begin{array}{c}\text { Grade } \mathrm{G} \\
\left(25 \mathrm{~kg} / \mathrm{mm}^{2}\right)\end{array}$ & $\begin{array}{c}\text { Grade } A \\
\left(25 \mathrm{~kg} / \mathrm{mm}^{2}\right)\end{array}$ \\
\hline WI & 9 (coil) & $\begin{array}{l}\mathrm{L} \\
\mathrm{T}\end{array}$ & $\begin{array}{l}-87 \\
-82\end{array}$ & $\begin{array}{l}-50 \\
-40\end{array}$ & $\begin{array}{l}-71 \\
-69\end{array}$ & $\begin{array}{l}-47 \\
-45\end{array}$ \\
\hline
\end{tabular}

Table 18 Results of double tension test of semikilled steel plates as shown in Table 5, 8 and 10

\begin{tabular}{|c|c|c|c|c|c|c|c|c|}
\hline \multirow{2}{*}{ Steel } & \multirow{2}{*}{$\begin{array}{c}\text { Thickness (shape) } \\
\mathrm{mm}\end{array}$} & \multirow{2}{*}{$\begin{array}{c}\text { Direction } \\
\text { of } \\
\text { sampling }\end{array}$} & \multirow{2}{*}{$\begin{array}{l}\mathrm{p} T \mathrm{~s} \\
{ }^{\circ} \mathrm{C}\end{array}$} & \multirow{2}{*}{$\begin{array}{l}\text { Applied } \\
\text { stress } \\
\mathrm{kg} / \mathrm{mm}^{2}\end{array}$} & \multicolumn{4}{|c|}{$\begin{array}{c}\text { Critical temperature from } \\
\text { double tension test }{ }^{\circ} \mathrm{C}\end{array} \mid \begin{array}{l}\text { TS according to WES }{ }^{\circ} \mathrm{C} \\
\end{array}$} \\
\hline & & & & & Flat* & Gradient* & Grade G & Grade A \\
\hline \multirow{2}{*}{ III } & \multirow{2}{*}{7.8 (coil) } & L & 0 & 20 & -18 & -10 & -25 & -2 \\
\hline & & $\mathbf{T}$ & -10 & 20 & -23 & -13 & -32 & -10 \\
\hline \multirow{2}{*}{$\mathbb{N}$} & \multirow{2}{*}{4.7 (coil) } & $\mathbf{L}$ & -20 & 25 & -30 & -15 & -36 & -14 \\
\hline & & $\mathrm{T}$ & -25 & 25 & -40 & -27 & -40 & -17 \\
\hline
\end{tabular}

*) Distribution of temperature across width of specimen

Table 19 Results of double tension test of both plates with and without niobium (as rolled in works on the same condition of rolling) as shown in Table 11 and 12

\begin{tabular}{|c|c|c|c|c|c|c|c|c|}
\hline \multirow{2}{*}{ Steel } & \multirow{2}{*}{$\begin{array}{c}\text { Thickness (shape) } \\
\text { mm }\end{array}$} & \multirow{2}{*}{$\left|\begin{array}{c}\text { Direction } \\
\text { of } \\
\text { sampling }\end{array}\right|$} & \multirow{2}{*}{$\begin{array}{l}\mathrm{vTE} \\
{ }^{\circ} \mathrm{C}\end{array}$} & \multirow{2}{*}{$\begin{array}{l}\text { Applied } \\
\text { stress } \\
\mathrm{kg} / \mathrm{mm}^{2}\end{array}$} & \multicolumn{2}{|c|}{$\begin{array}{l}\text { Critical temperature from } \\
\text { double tension test }{ }^{\circ} \mathrm{C}\end{array}$} & \multicolumn{2}{|c|}{$\begin{array}{l}\text { Critical temperature from } \\
\mathrm{VT}_{E} \text { according to WES }{ }^{\circ} \mathrm{C}\end{array}$} \\
\hline & & & & & Flat & Gradient & Grade G & Grade $\mathbf{A}$ \\
\hline With Nb & \multirow{2}{*}{$6.4(\mathrm{coil})$} & $\begin{array}{l}\mathbf{L} \\
\mathbf{T}\end{array}$ & $\begin{array}{l}-25 \\
-30\end{array}$ & \multirow{2}{*}{20} & $\begin{array}{l}-23 \\
-30\end{array}$ & $\begin{array}{l}-13 \\
-20\end{array}$ & $\begin{array}{l}-30 \\
-35\end{array}$ & $\begin{array}{l}-10 \\
-10\end{array}$ \\
\hline Without Nb & & $\begin{array}{l}\mathbf{L} \\
\mathrm{T}\end{array}$ & $\begin{array}{r}-15 \\
0\end{array}$ & & $\begin{array}{l}-17 \\
-10\end{array}$ & $\begin{array}{r}0 \\
+2\end{array}$ & $\begin{array}{l}-25 \\
-15 \\
\end{array}$ & $\begin{array}{r}0 \\
+10 \\
\end{array}$ \\
\hline
\end{tabular}

験の成績を示す. 使用応力が 20 るいは $25 \mathrm{~kg} / \mathrm{mm}^{2}$ の 時の最低使用温度をWES.の低温棈造用鋼材兵判定基 準案 ${ }^{14}$ によって求めて併示している. WES のA種とし ての温度す $\mathrm{T}_{50}$ より推定される最低使用温度よりは多 くの場合低温側にあってかならずしも両者は一致してい ないが，シャルピー衝整試験の吸収エネルギーにみられ たようなしとT方向の間の大きな差異はここでは認めら
れない，WES の新しいG種としての最低使用温度がも っとも劣っている鋼板であおよそ $-10^{\circ} \mathrm{C}$ 以下であるか ら，一般の溶接構造用材としては十分な䩒性をすつとい うことができよう。なお $T_{50}$ の值は Table 17 にみら れるように鋼VII低合金鋼板の場合があっと无低温例に あり優れている.

Table 18 および19に二重引張り試験成績の例を示 
す. Table 18 では鋼板亚および IV の降伏点をそれぞれ 40 おび $50 \mathrm{~kg} / \mathrm{mm}^{2}$ として, 降伏点の $1 / 2$ の応力下にお ける脆性亀裂停止温度を求めている. 2 重引張り試験の 結果は, T方向の方がむしろ優れた成績を示しているこ とがわかる、またシャルピー衝撃試験の破面遷移温度 ${ }^{\mathrm{P}} \mathrm{T}_{\mathrm{S}}$ から WES によって求めた最低使用温度とは比較 的よく一致しているといえよう.

Table 19 では $\mathrm{Nb}$ を添加しない鋼板との比較を行な ったものであるが, Table 12 のシャルピー衝撃試験の 場合とおなじく， $\mathrm{Nb}$ を添加することによって引張り張 度がいちじるしく增加しているにあかかわらず，2 重引 張り試験の成績はかえって優れている.

\section{4 ミクロ組織}

これらの鋼板のミクロ組織を Photo. 2〜4 に示す.

Photo. 2 には鋼Iによる板厚 $6 \mathrm{~mm}$ の平板状鋼板と 板厚 $6.4 \mathrm{~mm}$ のコイル状鋼板のミクロ組織を比較して 示している.コイル状鋼板は熱間圧延後ただちに比較的 高温度で巻きとられたのち徐冷されるので, パーライト 組織はかなり球状化している，さきにのべたように，コ イル状鋼板の衙撃性質が優れているのはこのような組織 の変化によるものと考えられる. コイル状鋼板における $\mathrm{Nb}$ の添加による引張り強度増加はその炭窒化物の析 出硬化作用によるものであり, したがってパーライト組 織が球状化してあ軟化の程度は少ないあのと考えられ る.

平板状鋼板のミクロ組織を Photo. 2 (板厚 $6 \mathrm{~mm}$ ) お よび Photo. 3 (板厚12および $32 \mathrm{~mm}$ ) に示している. 従来の $\mathrm{Nb}$ を添加していない鋼板に比較して層状組織の 傾向が強く, 組織は多少微細化している. またオーステ ナイト中に固溶していた $\mathrm{Nb}$ の効果として，パーライト

a

b

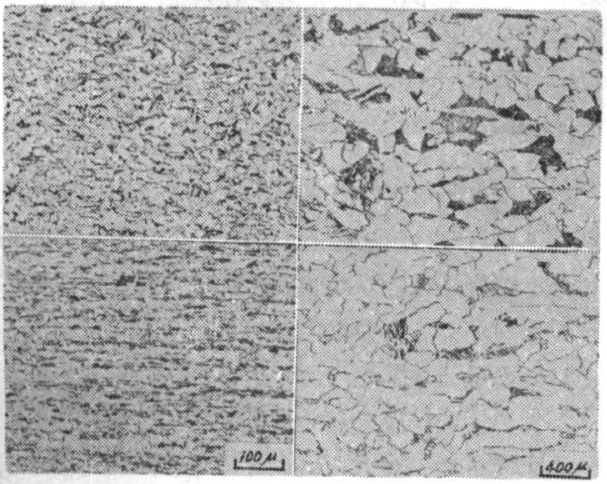

Photo. 2 Micro-structure of large coil and plate of low carbon low manganse steel containing niobium $0.035 \%$ (Steel I in Table 4, 7 and 9)

Photo. a: flat plate as rolled, $6 \mathrm{~mm}$ thick Photo. b: coil plate as rolled, $6.4 \mathrm{~mm}$ thick a

b

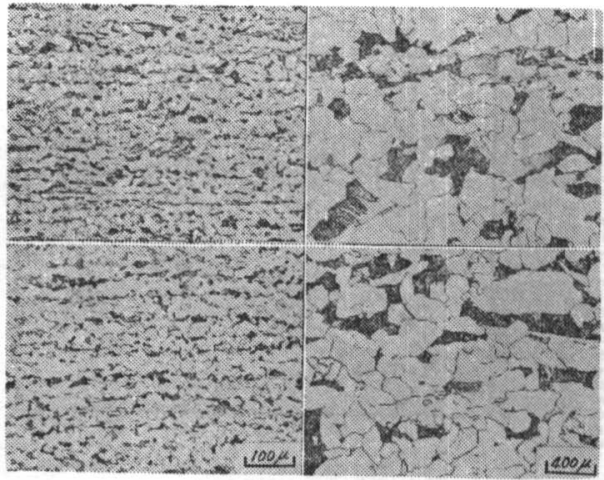

Photo. 3 Micro-structure of large plates of low carbon low manganese steel contain. ing niobium $0.051 \%$ (Steel II in Table 4, 7 and 9)

Photo a: flat plate as rolled, $12 \mathrm{~mm}$ thick Photo b: flat plate as rolled, $32 \mathrm{~mm}$ thick

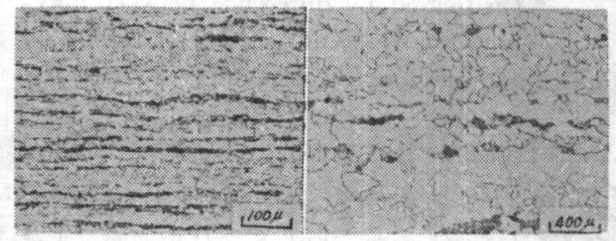

Photo 4 Micro-structure of large coil plate of low carbon low alloy steel containing niobium and vanadium (Steel VII in Table 6, 13 and 14)

組織の中には多少のベーナイト組織が混在しているよう である. 平板状鋼板における $\mathrm{Nb}$ の添加による引張り強 度の増加には, 析出硬化作用のほ加にこのような組織変 化む原因しているあのと考えられる.

平板状鋼板の衝撃性質を多少でも改善するためには, 圧延のままの鋼板に焼なまし処理を加えてコイル状銶板 にみられる程度の球状化をほどとす方法が考えられる. この方法は圧延のままの鋼板にありがちな性質のばらつ きを少なくする効果ああろう.

また板厚が $12 \mathrm{~mm}$ 前後まではコイル状に巻きとるこ とができるので, 板厚が薄い場合にはできるだけコイル 状鋼板を利用する方が靬性の点で優れている．したがっ て大径の溶接鋼管をストレートシームを溶接して造る場 合にも, コイル状鋼板を巾方向にも溶接してその巾の寸 法の不足を補ない， 2 本以上の管軸に平行なストレート シームを溶接して造る方法などが考えられる.

\section{5 溶 接 性}

溶接性試験としては, 溶接部最高硬度試験, 溶接ビー ド曲げ試験, スリット形溶接割れ試験, 溶接継手の引張 り，曲げおよびシャルピー衞撃試験などを実施した。 


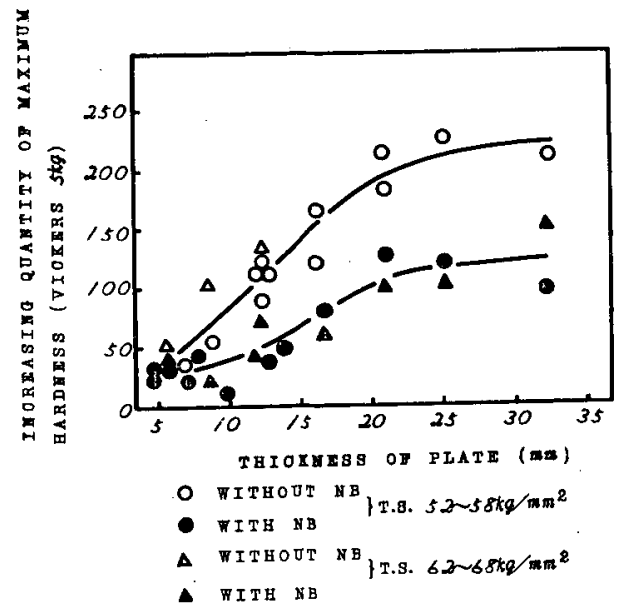

Fig. 8 Effect of niobium addition and thickness of plate on increasing quantity of max imum hardness at heat-affected zone (Estimated by difference between max imum hardness at heat-affected zone by arc-welding and at unaffected zone)

さきに Fig. 6 に括いて Nb の深加によって溶接熱 影響部の最高硬度と母材硬度との差すなわ硬化量が小 さくなることを示したが，Fig. 8 では板厚がおよそ 10 $\mathrm{mm}$ を超えると $\mathrm{Nb}$ の有無によってその便化量に朋暸 な差が認められるととを示している.

供試釦板の板厚はおよを $5 \mathrm{~mm}$ から $32 \mathrm{~mm}$ まで, 低合金鋼の場合は $9 \mathrm{~mm}$ であるが，ての䇫团ではいず れの試験においても問題となる点はまったく認められな い.

\section{5. 総括}

以上压延のままの鋼板の性質にお上湀す $\mathrm{Nb}$ の少量添 加効果をVの添加の場合之比較して明らかにするために 小鋼塊を溶製して行なった箺験の結果についてのべ，つ いで工場において大鋼塊から王延して造った $\mathrm{Nb}$ 添加高 張力鋼板の性質の特徽について報告した.

1) 压延のままの低炭素鋼板の引張り強度を 5 6 $\mathrm{kg} / \mathrm{mm}^{2}$ 程度增加させるためには，0.08\%前後のVを添 加した力が $\mathrm{Nb}$ の場合より屯衛撃性䫟の点でいくらか儤 れてはいるが， $0.05 \%$ 前後までの少量添加の範囲では $\mathrm{Nb}$ の方が引張り強度の堌加にはより大きな効果をおよ ぼす. Nb の是が $0.03 \%$ を超えると引張り強度の增加に 飽和する傾向がみられるので, $\mathrm{Nb}$ の引張り強度增加の 効果を最大に利用するには $0.03 \sim 0.05 \%$ の添加が滴当で ある。

2） $\mathrm{Nb}$ のてのような效果を利用して，従来の 41 キロ 級の低炭素鍽板を 50 キロあるいは 55 キ口級の銓板に変
え，50キロ級の低炭素低マンガン鋼板を60キ口級の鋼板 に変え,フェライト・パーライト組織のままではじめて 非調質型の60キロ鋼板をもつととができたというととが できよう，さらに低炭素の低合金鋼に NbとVを添加す るととによって衝撃性質の一層優れた鋼板をつくるとと むできる.

3) 引張り強度の中であとくに降伏点の増加が大きい ので, 従来の $\mathrm{Nb}$ を添加しない鋼板よりも降伏比が高い のが 1 つの特微であるが, 衝撃性質に特異な現象がみら れる.すなわち引張り強度が高いだけに衝撃吸収エネル ギーは全般に低く問題となる場合があるが，衝整破面遷 移温度は $\mathrm{Nb}$ を添加しない低引張り強度の鋼板に比較し ても少っていない，板厚が薄い鋼板の圧延方向に直角な 方向のシャルピー衡慗試験では, $\mathrm{vT}_{10}$ あるいは ${ }_{5} \mathrm{~T}_{1.0}$ といった低エネルギー遷移温度がかえって $\mathrm{vT}_{\mathrm{S}}$ や $\mathrm{P} \mathrm{T}_{\mathrm{S}}$ といった破面遷移温度よりも高温となるような場合さえ みられる。

4) 衝撃破面遷移温度はかなり優れているので, 勒性 の判定基準に吸収エネルギーを採用するととを止めて新 しくその破面遷移温度を使用することを提案している溶 接協会の低温用鋼板材質判定規準案に照らせば問題はな い.プレスノッチクラックスターター試験および 2 重引 張り武験によってとの鋁板の実用性を検討した結果もこ れを裹付けるむのであった。

5) 熱間压延後直ちに卷きとられるコイル状鋼板では 一般にパーライト組織の球状化の傾问など踥なましの効 果が現われて軟化するが，Nb 添加鍓板ではその析出硬 化作用のためにわずかしか低下しないという特徴もみら れる. 板厚など寸法の点で巻きとることのできない平板 状鋼板の靱性を多少でも向上させるためには，埊なまし 処理を加えてコイル状鋼板にみられるような球状化をほ どこす方法が考えられる。

\section{6. 結音}

$\mathrm{Nb}$ 添加非調質高張力鋼板がこれまで街整性質がそれ ほど問題とならない溶接棈造の部材としておるに使用さ れ, またその経済性のみが強調されてきたのは, 衡揧吸 収エネルギーが劣るという欠点のためであったが，この 点はそれほど重要な問題とは考えられない. 工場におけ る圧延条件の管理が幑底して王延のままの鋼板にありが ちな性質のばらつきがさらに少なくなり，いっぽう衙撃 性犋化関する認識が改たまるとと屯に今後さらにその利 用価値が高まるすのと思われる。

鋼板の衙慗忣収エネルギーを高め，上くに任延方问に 直角な方向の吸収エネルギーを向上させて方何性を少な くするために，非金属介在物の形態を变えて压延方问に 
よく伸びたリボン型から卵型に変化させたり ${ }^{15) ， ま た そ ~}$

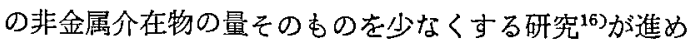
られている．しかしたとえば硫化物系の介在物が増加す ればその衝撃試験片の脆性破面が少なくなるという現象 さえみられて，硫化物系介在物を減らしても現在もっと あ重要とされている衝撃破面遷移温度を向上させる効果 は期待できない17).最近の脆性破壊の発生に関する研

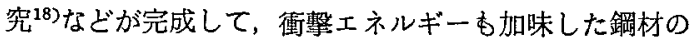
敬性判定の規準が確立されるのを期待したい。

なお $\mathrm{Nb}$ 添加非調質高張力鋼板の実用性をさらに明確 にするために，ての鋼板から溶接して造った大径の鋼管 について低温における破壊実験を行なったが，第 2 報に その結果を報告する。

\section{参若 文 献}

1) F.M. Becket and R. Franks : "Low alloy steel", U.S. Patent 2, 194, 1781940

2) 同上: "Steel", U.S. Patent 2, 264, 3551941

3) "Toughen mild carbon steels with columbium", Iron Age, 182 (1958), No. 18, 96

4) F.W. Starratt : "Columbium-treated steels", J of metals, 10 (1958), 799

5) W.B. Morrison: "The influence of small niobium additions on the properties of carbon-manganese steels", J. Iron and Steel Inst., 201 (1963), $317 \sim 325$
6）木原ほか: :"マンガンシリコン系高張力鋼の溶接性", 溶接学会誌, 25 (1956), 242 248

7) 木原ほか："60キ口高张力銅の溶接性の研究 (1) （4)，溶接学会 誌, 26 (1957)，520 525, 547 553, 612 621，670 -674

8）木原ほか：“原子妒用高張力鐝の溶接に関する研究，その1～その $6 "$, 溶接技術, 10 (1962)，No. 5, 20 38， No. 6, 30 59, No. $7,37 \sim 49$, No. $8,38 \sim 54$, No. $9,30 \sim 54$, No. 10,44 $-48$

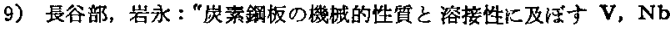
の影箩”，溶接学会誌，33(1964)，824

10）溶接協会：“WES 规格，低温棈造用鋼板判定規海 (案)"，溶接技 術，9(1961)，No. 2，59 65

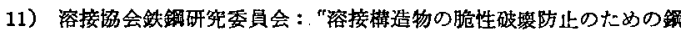
材の材質判定基準の確立に関する試験研究実施基準"，溶接技術， 8 (1960), 809

12) 同上, $8(1960), 807,808$

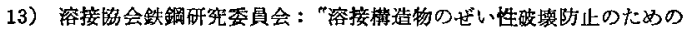

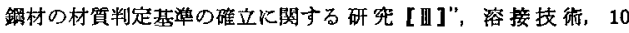
(1962), No. 12,48

14）溶接㙝会：“低温棈造用鎆板材質判定基準(案)，39-3 改言”，1964 年 3 月

15）たとえば E.J. Lichy, G.C. Duderstadt, N.L. Samways : "Control of sulfide shape in low carbon Al-killed steel", J. of Metals, 17 (1965), 769 775

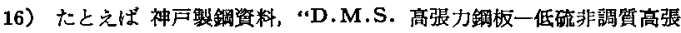
力鋼板", 1966

17) J.M. Hodge, R.H. Frazier, F.W. Boulger : “The effects of sulfur on the notch toughness of heat-treated steels", Trans. Met. Soc., Amer. Inst, Min., Met., \& Pet. Eng., 215 (1959), 745 753

18）たとえば，池田：“脆性破㘼の発生に関可る最近の研究”，溶接学 全踥, 34 (1965)，1039 1048

\section{9年 I.I.W. 年次大会準備委員会委員}

\begin{tabular}{|c|c|c|}
\hline $\begin{array}{l}\text { 会 長 } \\
\text { 副会長 }\end{array}$ & $\begin{array}{l}\text { 岡田実 } \\
\text { 仲 威雄 }\end{array}$ & $\begin{array}{l}\text { 大阪大学長 学術会議会員 } \\
\text { 東京大学工学部長 " 財務委員長 }\end{array}$ \\
\hline " & 木原 博 & 東京大学教授 \\
\hline " & 小林 卓郎 & 東北大学教授 \\
\hline 員 & 青术 楠男 & 早稲田大学名誉教授 学士院会員 \\
\hline " & 安藤 弘平 & 大阪大学教授 \\
\hline " & 大塚 誠之 & 日本大学教授 \\
\hline " & 大西厳 & 大阪大学教授 \\
\hline " & 木下 昌雄 & $\begin{array}{l}\text { 日立造船侏取締役技研所長 学術 } \\
\text { 会議会員 }\end{array}$ \\
\hline " & 佐 藤 & 三菱重工業湘談役 \\
\hline " & 柴田 晴彦 & 武蔵工業大学教授 \\
\hline " & 真 藤 恒 & 石川島播磨重工業侏 \\
\hline 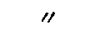 & 関口春次郎 & 大同工業大学教授 \\
\hline & 田坂 輝敬 & 富士 \\
\hline
\end{tabular}

\begin{tabular}{|c|c|c|}
\hline 委 員 & 鶴 田 明 & 早稲田大学教授 \\
\hline " & 手塚 敬三 & 日本ウェルディングロッド侏常務 \\
\hline$" \prime$ & 永井 信雄 & 侏神戸製鋼所 常務 \\
\hline " & 中 村 & $\begin{array}{l}\text { 石川島播磨重工業獭 技研所長 } \\
\text { 学術会議会員 }\end{array}$ \\
\hline$" \prime$ & 橋本 宇一 & 金属材料技術研究所長 \\
\hline$" 1$ & 藤木 俊三 & $\begin{array}{l}\text { 八幡製鉄特 技研所長 学術会議 } \\
\text { 会員 }\end{array}$ \\
\hline$" \prime$ & 松原与三松 & 日立造船侏 会長 \\
\hline " & 三上 博 & 職業訓練大学校教授 \\
\hline$" \prime$ & 湯川 & 八幡製鉄侏 副社長 \\
\hline$" \prime$ & 横田 清義 & 早稲田大学教授 \\
\hline " & 吉識 雅夫 & 東京大学教授 学術会議会員 \\
\hline " & 渡辺 正紀 & 大阪大学教授 \\
\hline
\end{tabular}

